\title{
PENGARUH METODE PEMBELAJARAN BRAINSTORMING TERHADAP KETERAMPILAN MENULIS ARTIKEL ILMIAH
}

\author{
Hariyadi $^{1}$, Al Ashadi Alimin'2, Eti Ramaniyar ${ }^{3}$, \\ ${ }^{1}$ Program Studi Pendidikan Bahasa dan Sastra Indonesia, \\ Fakultas Pendidikan Bahasa dan Seni, IKIP PGRI Pontianak \\ email korespondensi: hariyadiaf@gmail.com
}

\begin{abstract}
Abstrak
Penelitian ini bertujuan untuk mengetahui pengaruh metode pembelajaran brainstorming terhadap keterampilan menulis artikel ilmiah pada mahasiswa Program Studi Pendidikan Bahasa dan Sastra Indonesia. Penelitian ini merupakan penelitian kuantitatif dengan metode eksperimen. Teknik pengumpulan data yang digunakan adalah teknik pengukuran. Data dianalisis menggunakan rumus rata-rata dan uji $\mathrm{T}$ untuk melihat seberapa besar pengaruh antar variabel. Hasil penelitian menunjukan rata-rata keterampilan mahasiswa menulis artikel ilmiah sebelum diterapkan metode brainstorming yaitu sebesar 70,77 dengan kategori Baik. Hasil rata-rata keterampilan menulis artikel ilmiah sesudah diterapkan metode brainstorming yaitu sebesar 78,83 dengan kategori Baik. Adapun diketahui nilai Sig. (2-tailed) sebesar $0,000<0,05$, maka sebagaimana dasar pengambilan keputusan dalam uji independent sample $t$ test dapat disimpulkan bahwa Ho ditolah dan Ha diterima. Dengan demikian dapat disimpulkan bahwa ada perbedaan yang signifikan (nyata) antara keterampilan menulis artikel ilmiah mahasiswa sebelum dan sesudah diterapkan Metode pembelajaran brainstorming.
\end{abstract}

Kata Kunci : penerapan metode pembelajaran, brainstorming, keterampilan menulis artikel ilmiah

\begin{abstract}
This study aims to determine the effect of brainstorming learning methods on scientific article writing skills in students of the Indonesian Language and Literature Education Study Program. This research is a quantitative research with experimental method. The data collection technique used is the measurement technique. Data were analyzed using the average formula and the T test to see how much influence between variables. The results showed the average skills of students writing scientific articles before applying the brainstorming method that is equal to 70.77 with the Good category. The average results of scientific article writing skills after applying the brainstorming method that is equal to 78.83 with the Good category. The value of Sig. (2-tailed) of $0,000<0.05$, then as the basis for decision making in the independent sample $t$ test, it can be concluded that Ho was rejected and Ha was accepted. Thus it can be concluded that there are significant (real) differences between students' scientific article writing skills before and after the brainstorming learning method is applied.
\end{abstract}

Keywords: application of learning methods, brainstorming, scientific article writing skills 


\section{PENDAHULUAN}

Menulis artikel ilmiah merupakan tulisan tentang suatu masalah yang memiliki unsur keilmiahan (Ghufron, 2016). Seorang penulis harus mampu menuangkan pemikiran, ide, dan gagasan yang disusun dengan sistematika keilmiahan atau sistematika penulisan artikel ilmiah (Santoso dan Sos, 2015; Resmini, 2003; Jaedun, 2011). Tentu keterampilan dalam mengambangkan pemikiran dan gagasan serta pemahaman terhadap sistematika penulisan karya ilmiah ini menjadi bagian yang sangat penting bagi dalam menunjang keberhasilan menulis artikel ilmiah.

Sesuai dengan surat edaran Dirjen Dikti No. 152/E/T/2012 tentang kewajiban publikasi ilmiah bagi mahaasiswa S1, S2, dan S3. Dalam aturan tersebut ditegaskan bahwa lulusan program sarjana harus menghasilkan makalah yang terbit pada jurnal ilmiah. Oleh karena itu keterampilan menulis artikel ilmiah bagi mahasiswa merupakan keterampilan yang wajib dikuasi mahasiswa, sebagaimana yang diutarakan (Persadha, 2016) "Melalui kegiatan menulis karya ilmiah, mahasiswa diharapkan dapat mengkomunikasikan informasi, pengetahuan baru, gagasan, kajian, dan hasil penelitian”

Untuk menjawab tantangan aturan kebijakan tersebut, IKIP PGRI Pontianak, sesuai dengan SK Rektor IKIP PGRI Pontianak No: L.202.193./REK/2015 tentang Pemberlakuan Kurikulum KKNI Tahun Akademik 2015/2016 terutama di Kurikulum Program Studi Pendidikan Bahasa dan Sastra Indonesia terdapat mata kuliah seminar Penelitian yang terdiri dari mata kuliah Seminar Penelitian Bahasa dan Pembelajarannya, Seminar Penelitian Sastra dan Pembelajarannya, dan Seminar Penelitian Pendidikan BSI.

Berdasarkan hasil pra observasi di lapangan, ditemukan bahwa kualitas artikel ilmiah yang dihasilkan oleh mahasiswa masih rendah. ada beberapa permsalahan yang menjadi penyebab rendahnya kualitas artikel ilmiah mahasiswa. Pertama, kreativitas mahasiswa masih rendah, hal ini dibuktikan dengan masih banyaknya artikel yang terindikasi plagiasi atau sekedar kopi paste dari internet atau artikel ilmiah orang lain. Kedua, rendahnya motivasi mahasiswa dalam 
menulis, berdasarkan hasil wawancara dengan dosen pengampu mata kuliah seminar bahwa mahasiswa kurang termotivasi dalam menulis artikel, mahasiswa beranggapan bahwa menulis artikel ilmiah itu sulit. Ketiga, kurangnya pemahaman terhadap sistematika penulisan artikel ilmiah.

Berdasarkan permasalahan yang dipaparkan di atas, perlunya ada solusi yang akan diterapkan untuk memperbaiki keterampilan menulis artikel ilmiah mahasiswa. Cara yang dapat digunakan untuk memperbaiki hasil belajar yaitu dosen dapat menerapkan model pembelajaran yang dapat merangsang kreativitas mahasiswa dalam mengungkapkan gagasan atau ide ke dalam bentuk tulisan sehingga mahasiswa memiliki motivasi bahwa menulis artikel ilmiah tidaklah sulit.

Penelitian ini akan menerapakan metode brainstorming. Metode brainstorming ini pertama dipopulerkan oleh Alex F. Osborn yang tertulis di dalam bukunya yang berjudul "Applied Imagination". (Sani, 2013) metode curah pendapat brainstorming adalah metode pengumpulan-pengumpulan sejumlah besar gagasan dari sekelompok orang dalam waktu singkat, metode ini sering digunakan dalam pemecahan/ penyelesaian masalah yang kreatif dan dapat digunakan sendiri atau sebagai bagian dari strategi lain. Metode ini memiliki beberapa kelebihan seperti yang diutarakan (Roestiyah, 2008) a. Anak-anak aktif berpikir untuk menyatakan pendapat. b. Melatih siswa berpikir dengan cepat dan tersusun logis. c. Merangsang siswa untuk selalu siap berpendapat yang berhubungan dengan masalah yang diberikan oleh guru. d. Meningkatkan partisipasi siswa dalam menerima pelajaran. e. Siswa yang kurang aktif mendapat bantuan dari temannya yang pandai atau dari guru. f. Terjadi persaingan yang sehat. g. Anak merasa bebas dan bergembira. h. Suasana demokrasi dan disiplin dapat ditumbuhan.

Penelitian terkait penggunaan metode brainstorming dalam pembelajaran menulis secara umum telah banyak diteliti oleh peneliti sebelumnya. Penggunaan teknik pembelajaran brainstorming (Chaniago, 2014) terdapat pengaruh penggunaan teknik pembelajaran brainstorming kemampuan menulis paragraf 
deskripsi siswa kelas x SMA menunjukkan bahwa terdapat pengaruh yang signifikan. Kajian serupa telah dilakukan oleh (Simanjuntak dan Mubarak, 2018) kemampuan menulis paragraf argumentasi mahasiswa di Universitas Putera Batam dengan menggunakan metode brainstorming diperoleh nilai rata-rata sebesar 75,88 .

Berdasarkan uraian di atas, peneliti tertarik untuk melakukan penelitian dengan judul "Pengaruh Metode Pembelajaran Brainstorming terhadap Keterampilan menulis artikel ilmiah pada Mahasiswa Semester VI Program Studi Pendidikan Bahasa dan Sastra Indonesia Tahun Akademik 2018/2019”.

\section{METODE PENELITIAN}

Penelitian ini menggunakan jenis penelitian eksperimen. Sejalan dengan masalah yang telah diajukan yaitu ingin mencari pengaruh perlakuan Metode Pembelajaran Brainstorming terhadap keterampilan menulis artikel ilmiah. Hal tersebut didukung oleh pendapat (Sugiyono, 2017) metode penelitian eksperimen dapat diartikan sebagai metode penelitian yang digunakan untuk mencari pengaruh perlakukan tertentu terhadap yang lain dalam kondisi yang terkendalikan. Bentuk dari penelitian ini yaitu Pre-Experimenal Design. Rancangan atau desain yang digunakan dalam penelitian ini adalah One Group Pretest-Posttest Design. Menurut (Sugiyono, 2017) rancangan ini memberikan hasil perlakuan dapat diketahui lebih akurat, karena dapat membandingkan dengan keadaan sebelum diberikan perlakuan.

Dalam penelitian ini, penentuan jumlah sampel dengan teknik sampling purposive yakni penentuan sampel dengan pertimbangan tertentu. Berdasarkan hal tersebut maka peneliti memilih kelas A Sore sebagai sampel dalam penelitian ini. Adapun hal yang menjadi pertimbangannya adalah a) nilai dari keterampilan menulis pada kelas tersebut masih rendah, b) keaktifan mahasiswa di kelas tersebut masih kurang, c) dan mahasiswa masih kurang berpartisipasi pada saat proses pembelajaran.

Teknik yang digunakan untuk mengumpulkan data dalam penelitian ini yaitu teknik pengukuran dengan alat pengumpul datanya berupa tes. Tes digunakan 
untuk mengukur produk atau hasil sebuah artikel ilmiah. Instrumen yang telah dibuat terlebih dahulu divalidasi isi dan diujicobakan sehingga instrumen yang berkategori baik yang akan digunakan dalam penelitian.

Analisis data dimaksudkan untuk menguji hipotesis yang telah diajukan. Analisis data dalam penelitian ini, mencakup analisis data secara deskriptif dan analisis data secara inferensial. Analisis data secara deskriptif, meliputi pendeskripsian tendensi sentral dan tendensi penyebaran, penyusunan distribusi frekuensi nilai dan histogramnya. Sementara itu, analisis data secara inferensial digunakan untuk keperluan pengujian hipotesis. Pengujian hipotesis menggunakan uji-t.

\section{HASIL PENELITIAN DAN PEMBAHASAN}

Data dalam penelitian ini meliputi: diskripsi data, hasil uji prasyarat, hasil uji hipotesis, pembahasan hasil analisis data, dan keterbatasan penelitian. Adapun berbagai hal pembahasan tersebut peneliti jabarkan sebagai berikut ini.

\section{Nilai Keterampilan Menulis Artikel Ilmiah Mahasiswa Sebelum diterapkan Metode Pembelajaran Brainstorming.}

Data mengenai nilai keterampilan menulis artikel mahasiswa sebelum diterapkan metode pembelajaran brainstorming ini diperoleh melalui tes unjuk kerja yaitu berupa penugasan kepada mahassiwa untuk menulis sebuah artikel hasil pengamatan di lapangan pada mata kuliah Psikolinguistik. Berdasarkan data penelitian yang didapat dan diolah menggunakan bantuan program Microsoft excel, untuk nilai keterampilan menulis artikel mahasiswa sebelum diterapkan metode pembelajaran brainstorming hasilnya dapat dilihat pada tabel berikut ini.

Tabel 1. Deskripsi Skor Keterampilan Mahasiswa Sebelum diterapkan Metode Pembelajaran Brainstorming

\begin{tabular}{lc}
\hline Rata-rata & 70,77 \\
\hline Nilai Tertinggi & 88 \\
\hline Nilai Terendah & 55 \\
\hline Median & 72 \\
\hline Modus & 73 \\
\hline Standar Deviasi & 7,47 \\
\hline
\end{tabular}


Berdasarkan tabel 1. tersebut, diketahui nilai rata-rata keterampilan menulis artikel ilmiah mahasiswa sebelum diterapkan metode pembelajaran brainstorming adalah sebesar 70,77 dengan kategori Baik. Nilai tertinggi sebesar 88 dan nilai terendah sebesar 55. Adapun mediannya adalah 72, modus 73 , dan standar deviasi sebesar 7,47.

\section{Nilai Keterampilan Menulis Artikel Ilmiah Mahasiswa Setelah diterapkan Metode Pembelajaran Brainstorming.}

Data mengenai nilai keterampilan menulis artikel mahasiswa setelah diterapkan metode pembelajaran brainstorming ini diperoleh melalui tes unjuk kerja yaitu berupa penugasan kepada mahassiwa untuk menulis sebuah artikel hasil pengamatan di lapangan pada mata kuliah Psikolinguistik. Berdasarkan data penelitian yang didapat dan diolah menggunakan bantuan program Microsoft excel, untuk nilai keterampilan menulis artikel mahasiswa setelah diterapkan metode pembelajaran brainstorming hasilnya dapat dilihat pada tabel berikut ini.

Tabel 2. Deskripsi Skor Keterampilan Mahasiswa Setelah diterapkan Metode Pembelajaran Brainstorming

\begin{tabular}{cc}
\hline Rata-rata & 78,83 \\
\hline Nilai Tertinggi & 93 \\
\hline Nilai Terendah & 65 \\
\hline Median & 80 \\
\hline Modus & 80 \\
\hline Standar Deviasi & 7,64 \\
\hline
\end{tabular}

Berdasarkan tabel 2. tersebut, diketahui nilai rata-rata keterampilan menulis artikel ilmiah mahasiswa setelah diterapkan metode pembelajaran brainstorming adalah sebesar 78,83 dengan kategori Baik. Nilai tertinggi sebesar 93 dan nilai terendah sebesar 65. Adapun mediannya adalah 80, modus 80, dan standar deviasi sebesar 7,64.

\section{Perbandingan Nilai Pretest dan Posttest Keterampilan Menulis Artikel Ilmiah Mahasiswa}

Data mengenai perbandingan nilai pretest dan posttest ini diambil dari ratarata keseluruhan nilai mahasiswa. Kemudian membandingkan nilai tertinggi dan 
terendah, serta membandingkan kategori penilaian hasil keterampilan menulis artikel ilmiah antara nilai pretest dan nilai posttest. Deskripsi data ini disajikan dalam bentuk tabel dan histogram sebagai berikut ini.

Tabel 3. Perbandingan Nilai Pretest dan Posttest Keterampilan Menulis Artikel Ilmiah Mahasiswa

\begin{tabular}{lcccc} 
Deskripsi & Prestest & Posttest & Selisih & $\begin{array}{c}\text { Persentase } \\
\text { Selisih }\end{array}$ \\
\hline Rata-rata & 70,77 & 78,83 & 8,06 & $8,06 \%$ \\
\hline Nilai Tertinggi & 88 & 93 & 5 & $5 \%$ \\
\hline Nilai terrendah & 55 & 65 & 10 & $10 \%$ \\
\hline Kategori Sangat Baik & 2 & 11 & 9 & $25,71 \%$ \\
\hline Kategori Baik & 19 & 20 & 1 & $2,86 \%$ \\
\hline Kategori Cukup & 14 & 4 & -10 & $-28,57 \%$ \\
\hline kategori kurang & 0 & 0 & 0 & $0 \%$ \\
\hline
\end{tabular}

Berdasarkan tabel di atas, diketahui bahwa rata-rata nilai pretest yaitu sebesar 70,77 dan posttest sebesar 78,83. Selisih nilainya adalah 8,06\%. Dari perbandingan nilai rata-rata tadi dapat disimpulkan bahwa adanya perbedaan antara keterampilan mahasiswa dalam menulis artikel ilmiah sebelum diterapkan metode pembelajaran brainstorming dengan yang sesudah diterapkan model brainstorming.

\section{hasil uji prasyarat analisis}

Karakteristik data penelitian yang telah dikumpulkan sangat menentukan teknik analisis yang dipakai. Oleh sebab itu, sebelum analisis data secara inferensial untuk kepentingan pengujian hipotesis dilakukan, terlebih dahulu datadata tersebut perlu diadakan pemeriksaan atau diuji. Pengujian persyaratan meliputi: (1) pengujian normalitas dan (2) pengujian homogenitas. Lebih jelasnya uraian uji persyaratan analisis data dapat disampaikan sebagai berikut ini.

\section{uji normalitas data}

Uji normalitas dilakukan untuk mengetahui apakah data dalam penelitian ini berdistribusi normal atau tidak. Dalam penelitian ini, data yang dimaksudkan adalah data pretest dan posttest keterampilan menulis artikel mahasiswa. pengujian normalitas data ini dilakukan dengan teknik Kolmogorov simirnov. p-ISSN 2089-2810 
Analisis data ini menggunakan bantuan program SPSS. Adapun hasilnya dapat dilihat dalam tabel berikut ini.

Tests of Normality

\begin{tabular}{|l|r|r|r|r|r|c|}
\hline & \multicolumn{3}{|c|}{ Kolmogorov-Smirnov ${ }^{\mathrm{a}}$} & \multicolumn{3}{c|}{ Shapiro-Wilk } \\
\cline { 2 - 7 } & Statistic & \multicolumn{1}{c|}{$\mathrm{df}$} & \multicolumn{1}{c|}{ Sig. } & Statistic & \multicolumn{1}{c|}{ df } & \multicolumn{1}{c|}{ Sig. } \\
\hline Pretest & .086 & 35 & $\mathbf{. 2 0 0}$ & .985 & 35 & $\mathbf{. 9 0 8}$ \\
posttest & .132 & 35 & $\mathbf{. 1 2 6}$ & .964 & 35 & $\mathbf{. 3 0 3}$ \\
\hline
\end{tabular}

*. This is a lower bound of the true significance.

a. Lilliefors Significance Correction

Gambar 1: Hasil perhitungan normalitas data

Berdasarkan data di atas, pengujian normalitas data pretest dan posttest keterampilan menulis artikel mahasiswa hipotesis yang diuji adalah:

Ho : sampel berasal dari populasi yang berdistribusi normal.

$\mathrm{H}_{1} \quad$ : sampel tidak berasal dari populasi yang berdistribusi normal.

Dalam pengujian normalitas data ini peneliti menetapkan kriteria taraf signifikansi yaitu $\alpha=0,05$. Jika signifikansi yang diperoleh $>0,05$ maka sampel berasal dari populasi yang berdistribusi normal, dan jika signifikansi yang diperoleh $<0,05$ maka sampel tidak berasal dari populasi yang berdistribusi normal.

Berdasarkan hasil pengujian yang telah dilakukan, data pretest diperoleh nilai sig yaitu 0,200 >0,05, dan data posttest diperoleh nilai sig yaitu 0,126>0,05. Dengan demikian Ho diterima, sehingga sampel berasal dari populasi yang berdistribusi normal.

\section{uji homogenitas}

Uji homogenitas dilakukan untuk mengetahui apakah populasi-populasi yang dibandingkan mempunyai variansi yang sama (homogen) atau tidak. Uji homogenitas variansi populasi ini dilakukan untuk membandingkan variansi populasi pada masing-masing kelompok nilai pretest dan posttest. Dengan taraf siginifikansi 0,05, rangkuman hasil uji homogenitas variansi populasi menggunakan uji Levene's Test for Equality of Variances dan bantuan program 
SPSS terhadap data pretest dan posttest keterampilan menulis artikel ilmiah mahasiswa disajikan dalam tabel berikut ini.

\begin{tabular}{|l|r|r|}
\hline \multicolumn{2}{|c|}{ Independent Samples Test } \\
\hline \multicolumn{2}{|c|}{$\begin{array}{r}\text { Levene's Test for Equality of } \\
\text { Variances }\end{array}$} \\
\cline { 2 - 4 } & $\mathrm{F}$ & \multicolumn{2}{|c|}{ Sig. } \\
\hline $\begin{array}{l}\text { ket. Equal variances assumed } \\
\text { menulis } \\
\begin{array}{l}\text { artikel } \\
\text { ilmiah }\end{array}\end{array}$ & & \\
\hline
\end{tabular}

Gambar 2. Hasil Uji Homogenitas Variansi data

Berdasarkan hasil uji homogenitas variansi data pada Tabel 4.9. di atas, diperoleh nilai $\operatorname{sig}=0,779>0,05$. Hal ini berarti pada taraf signifikansi 0,05 , keputusan uji homogenitas variansi populasi adalah data pretest dan posttest keterampilan menulis artikel ilmiah mahasiswa diambil dari sampel yang homogen.

\section{hasil uji hipotesis}

Pengujian hipotesis dimaksudkan untuk mengetahui apakah hasil hipotesis nol $\left(\mathrm{H}_{\mathrm{o}}\right)$ yang diajukan ditolak atau sebaliknya pada taraf kepercayaan tertentu $(\alpha$ $=0,05$ hipotesis alternatif $\left(\mathrm{H}_{\mathrm{a}}\right)$ yang diajukan diterima. Hipotesis yang diuji disini adalah untuk melihat apakah ada perbedaan yang signifikan keterampilan menulis artikel ilmiah mahasiswa sebelum dan sesudah diterapkan metode pembelajaran brainstorming. Sesuai dengan hipotesis yang diajukan, maka hasil pengujian uji T atau T-Test (independent sample test) dengan bantuan pengolahan data menggunakan program SPSS didapatlah hasil sebagai berikut ini.

\begin{tabular}{llrrrrr} 
& \multicolumn{3}{c}{ Group Statistics } & & \\
& kelompok & $N$ & & Mean & Std. Deviation & Std. Error \\
ket. menulis artikel ilmiah & pretest & 35 & 70.77 & 7.472 & 1.263 \\
& postest & & 35 & 78.83 & 7.641 & 1.292 \\
p-ISSN 2089-2810 & & & & &
\end{tabular}


Gambar 3. Hasil Uji Hipotesis dengan Uji T

\begin{tabular}{|c|c|c|c|c|c|c|c|c|c|c|}
\hline \multicolumn{11}{|c|}{ Independent Samples Test } \\
\hline & & \multicolumn{2}{|c|}{$\begin{array}{l}\text { Levene's } \\
\text { Test for } \\
\text { Equality of } \\
\text { Variances }\end{array}$} & \multicolumn{7}{|c|}{ t-test for Equality of Means } \\
\hline & & \multirow[t]{2}{*}{$F$} & \multirow[t]{2}{*}{ Sig. } & \multirow[t]{2}{*}{$t$} & \multirow[t]{2}{*}{ df } & \multirow[t]{2}{*}{$\begin{array}{l}\text { Sig. } \\
(2- \\
\text { tailed) }\end{array}$} & \multirow[t]{2}{*}{$\begin{array}{l}\text { Mean } \\
\text { Differe } \\
\text { nce }\end{array}$} & \multirow[t]{2}{*}{$\begin{array}{l}\text { Std. } \\
\text { Error } \\
\text { Differ } \\
\text { ence }\end{array}$} & \multicolumn{2}{|c|}{$\begin{array}{l}95 \% \text { Confidence } \\
\text { Interval of the } \\
\text { Difference }\end{array}$} \\
\hline & & & & & & & & & Lower & Upper \\
\hline \multirow{2}{*}{$\begin{array}{l}\text { ket. } \\
\text { menulis } \\
\text { artikel } \\
\text { ilmiah }\end{array}$} & $\begin{array}{l}\text { Equal } \\
\text { variances } \\
\text { assumed }\end{array}$ & $\begin{array}{r}07 \\
9\end{array}$ & .779 & -4.460 & 68 & .000 & -8.057 & 1.806 & -11.662 & -4.452 \\
\hline & $\begin{array}{l}\text { Equal } \\
\text { variances } \\
\text { not } \\
\text { assumed }\end{array}$ & & & -4.460 & $\begin{array}{r}67 . \\
96 \\
6\end{array}$ & .000 & -8.057 & 1.806 & -11.662 & -4.452 \\
\hline
\end{tabular}

Gambar 4. Hasil Uji Hipotesis dengan Uji T

Berdasarkan gambar tabel ouput "independent samples test" pada bagian Equal variances assumed diketahui nilai Sig. (2-tailed) sebesar 0,000 $<0,05$, maka sebagaimana dasar pengambilan keputusan dalam uji independent sample $t$ test dapat disimpulkan bahwa Ho ditolak dan Ha diterima. Dengan demikian dapat disimpulkan bahwa ada perbedaan yang signifikan (nyata) antara keterampilan menulis artikel ilmiah mahasiswa sebelum dan sesudah diterapkan metode pembelajaran brainstorming.

Selanjutnya dari tabel output di atas diketahui nilai "mean difference" adalah sebesar $-8,057$. Nilai ini menunjukkan selisih antara rata-rata nilai keterampilan menulis artikel ilmiah mahasiswa pada pretest dengan rata-rata nilai posttest atau $70,77-78,83=-8,057$ dan selisih perbedaan tersebut adalah $-11,667$ sampai $-4,452$ (95\% Confidence interval of the difference lower upper).

\section{SIMPULAN}

Berdasarkan hasil analisis data dan pengujian hipotesis yang telah diuraikan, maka dapat ditarik beberapa simpulan hasil penelitian sebagai berikut ini.

Pertama, keterampilan menulis artikel ilmiah mahasiswa semester VI Program Studi Pendidikan Bahasa dan Sastra Indonesia Tahun Akademik 2018//2019 sebelum diterapkan metode pembelajaran brainstorming menunjukkan besarnya persentase tiap kategori adalah sangat baik sebesar 6\% (2 orang mahasiswa), baik sebesar 54\% (19 orang mahasiswa), cukup sebesar 40\% (14 orang mahasiswa), dan kurang sebesar 0\%. Berdasarkan persentase tersebut 
dapat terlihat hanya sedikit sekali mahasiswa yang memiliki kategori sangat baik dalam menulis artikel ilmiah sebelum diterapkan metode pembelajaran brainstorming.

Kedua, keterampilan menulis artikel ilmiah mahasiswa semester VI Program Studi Pendidikan Bahasa dan Sastra Indonesia Tahun Akademik 2018//2019 sesudah diterapkan metode pembelajaran brainstorming menunjukkan besarnya persentase tiap kategori adalah sangat baik sebesar 31\% (11 orang mahasiswa), baik sebesar $57 \%$ (20 orang mahasiswa), cukup sebesar $12 \%$ (4 orang mahasiswa), dan kurang sebesar 0\%. Berdasarkan persentase tersebut dapat terlihat adanya peningkatan atau perubahan pada nilai mahasiswa yang memiliki kategori sangat baik yaitu sebesar $31 \%$ dalam menulis artikel ilmiah sesudah diterapkan metode pembelajaran brainstorming.

Ketiga, bahwa ada perbedaan yang signifikan (nyata) antara keterampilan menulis artikel ilmiah mahasiswa sebelum dan sesudah diterapkan model pembelajaran brainstorming. Selanjutnya berdasarkan hasil uji hipotesis tersebut diketahui nilai "mean difference" adalah sebesar -8,057. Nilai ini menunjukkan selisih antara rata-rata nilai keterampilan menulis artikel ilmiah mahasiswa pada pretest dengan rata-rata nilai posttest atau 70,77-78,83 =-8,057 dan selisih perbedaan tersebut adalah -11,667 sampai -4,452 (95\% Confidence interval of the difference lower upper).

\section{DAFTAR PUSTAKA}

Chaniago, S. H. (2014). Pengaruh Penggunaan Teknik Pembelajaran Brainstorming Terhadap Kemampuan Menulis Paragraf Deskripsi Siswa Kelas X Sma Negeri 1 Bintang Bayu Kabupaten Serdang Bedagai Tahun Pembelajaran 2013/2014 (Doctoral dissertation, UNIMED).

Ghufron, S. (2014). Artikel Ilmiah: Anatomi, Bahasa, dan Kesalahannya. EDUKATA, 1(1), 1-10.

Jaedun, A. (2011). Pengembangan Profesionalisme Guru melalui Penulisan Karya Tulis Ilmiah. In Disampaikan Pada Kegiatan Seminar Karya Tulis Ilmiah dan Penelitian Tindakan Kelas di SMK Negeri (Vol. 1). 
Resmini, N. (2003). Penggunaan Bahasa dalam Artikel Ilmiah. Makalah Lokakarya Lomba Karya Tulis Mahasiswa dan Program Kreativitas Mahasiswa Tingkat FPBS UPI, 10.

Roestiyah N.K. (2008). Strategi Belajar Mengajar . Cet. VII. Jakarta : Rineka Cipta.

Persadha, D. A. K. (2016). Studi Kompetensi Kemampuan Menulis di Kalangan Mahasiswa. Muaddib: Studi Kependidikan dan Keislaman, 6(1), 1-20.

Sani, Ridwan Abdullah. (2013). Inovasi Pembelajaran. Jakarta: PT Bumi Aksara.

Santoso, H., \& Sos, S. (2015). Pengembangan berpikir kritis dan kreatif pustakawan dalam penulisan karya ilmiah. Jurnal Univeritas Negeri Malang. hlm, 1-17.

Simanjuntak, D. S. R., \& Mubarak, Z. H. (2018). Kemampuan Menulis Paragraf Argumentasi Mahasiswa Dengan Menggunakan Metode Brainstorming. Khazanah Ilmu Berazam, 1(2 SEPT), 94-101.

Sugiyono. (2015). Metode Penelitian Kualitatif, Kuantitatif, dan R\&D. Bandung: Alfabeta

Surat Dirjen Dikti No. 152/E/T/2012 : Tentang Wajib Publikasi Ilmiah Bagi S1, S2, dan S3

SK Rektor IKIP PGRI Pontianak No: L.202.193./REK/2015 tentang Pemberlakuan Kurikulum KKNI Tahun Akademik 2015/2016 